\title{
Changing Epidemiology of Respiratory Viral Infections in Hematopoietic Cell Transplant Recipients and Solid Organ Transplant Recipients
}

\author{
Christian Renaud, MD, MSc ${ }^{1}$ and Angela P. Campbell, MD, MPH ${ }^{1,2,3}$ \\ ${ }^{1}$ Vaccine and Infectious Disease Division, Fred Hutchinson Cancer Research Center, Seattle, \\ WA, United States \\ ${ }^{2}$ Clinical Research Division, Fred Hutchinson Cancer Research Center, Seattle, WA, United \\ States \\ ${ }^{3}$ Department of Pediatrics, University of Washington, Seattle, WA, United States
}

\section{Abstract}

\begin{abstract}
Purpose of review-New respiratory viruses have been discovered in recent years and new molecular diagnostic assays have been developed that improve our understanding of respiratory virus infections. This article will review the changing epidemiology of these viruses after hematopoietic stem cell and solid organ transplantation.
\end{abstract}

\begin{abstract}
Recent findings-Respiratory viruses are frequently detected in transplant recipients. A number of viruses have been newly discovered or emerged in the last decade, including human metapneumovirus, human bocavirus, new human coronaviruses and rhinoviruses, human polyomaviruses, and a new 2009 pandemic strain of influenza A/H1N1. The potential for these viruses to cause lower respiratory tract infections after transplantation varies, and is greatest for human metapneumovirus and H1N1 influenza, but appears to be limited for the other new viruses. Acute and long term complications in hematopoietic and solid organ transplant recipients are active areas of research.
\end{abstract}

Summary-Respiratory viral infections are frequently associated with significant morbidity following transplantation and are therefore of great clinical and epidemiologic interest. As new viruses are discovered, and more sensitive diagnostic methods are developed, defining the full impact of emerging respiratory viruses in transplant recipients must be elucidated by welldesigned clinical studies.

\section{Keywords}

Transplantation; human metapneumovirus; bocavirus; coronaviruses; rhinoviruses; polyomaviruses; influenza viruses

\section{Introduction}

Respiratory viruses cause potentially severe complications after solid organ (SOT) or hematopoietic stem cell transplantation (HCT). Within the last decade, new respiratory tract pathogens including human metapneumovirus (HMPV), human bocavirus (HBoV), new

Corresponding author: Angela Campbell Seattle Children's Hospital 4800 Sand Point Way NE Mailstop R-5441 Seattle WA 98105 angela.campbell@ seattlechildrens.org Phone: (206) 987-1883 Fax: (206) 987-3890.

Potential conflicts of interest. Dr. Campbell has received speaking fees from Viracor-IBT Laboratories, Inc. 
human coronaviruses (HCoV-NL63 and HCoV-HKU1), a new species of rhinovirus (HRV$\mathrm{C}$ ), and the KI and WU polyomaviruses (KIPyV and WUPyV) were discovered. However, epidemiologic and clinical characteristics of these viruses have yet to be fully described, particularly in transplant recipients. In addition, a new pandemic strain of influenza A/H1N1 emerged in 2009, which altered the usual seasonality of influenza and contributed to the changing epidemiology of influenza viruses after transplantation.

Advancement in the field of diagnostic virology has been significantly driven by the 2009 influenza A/H1N1 pandemic, as many clinical laboratories developed new molecular assays to diagnose respiratory viruses. Similarly, FDA approval in 2008 of the first multiplex PCR assay for detection of respiratory virus nucleic acids provided the opportunity for many laboratories that did not have expertise in traditional virology to diagnose a large number of viral pathogens [1]. Other multiplex panels and microarrays are being developed or are already available on the market as analyte-specific reagents (ASRs) [2**]. Comparative studies have shown increased sensitivity of real-time PCR assays and of these new multiplex panels compared with traditional viral culture and immunofluorescence testing $\left[1,3^{*}, 4^{*}\right]$.

\section{Respiratory viral infections and outcomes among transplant recipients}

Respiratory virus infections (RVIs) may present with a wide range of clinical syndromes among transplant recipients, from asymptomatic infection to severe pneumonia and death. Reported rates of infection and progression to lower respiratory tract disease vary by virus, and are in part dependent on viral detection methodology and study design.

\section{Hematopoietic stem cell transplantation}

Table 1 summarizes data from prospective and large retrospective published studies of RVIs among HCT recipients in the last 10 years, and Figure 1 provides cumulative incidence estimates from a recent prospective study in allogeneic HCT recipients [22]. In general, rates of progression to lower respiratory tract infection and deaths attributable to infection have decreased compared with earlier studies from the previous decade. The reasons for this are likely multifactorial, including less immunosuppressive transplant regimens, improved supportive care, more sensitive diagnostics, and early treatment strategies. For example, some studies did not report pneumonia or progression to pneumonia with influenza or RSV, but did specifically note that early diagnosis and treatment of upper respiratory tract infection appeared to be effective in preventing lower tract disease $[13,16]$.

In HCT recipients, risk factors for disease progression to pneumonia include infection early after transplantation, graft-versus-host disease, allogeneic HCT, and myeloablative conditioning, although the main factor consistently found to confer increased risk is lymphopenia $[7,8,14,15,18,30]$. These infections, independent of clinical symptoms and the specific virus, are often characterized by prolonged viral shedding, which may contribute to the emergence of antiviral resistance [31]. High rates of nosocomial acquisition have been described in outbreak situations, and co-infection with other viral, bacterial, or fungal agents can complicate infection with respiratory viruses [5, 9, 12, 18, 32, 33]. HCT recipients can potentially develop long-term sequelae including late airflow obstruction after RVIs [34].

Bronchiolitis obliterans syndrome (BOS) is a progressive lung alloreaction characterized by airflow obstruction that can occur following allogeneic HCT or allogeneic lung transplantation [35*]. Pneumonia with respiratory syncytial virus (RSV) or parainfluenza virus (PIV), and even upper respiratory tract infection with PIV, has been identified as a risk factor for BOS $[34,36]$. A recent pediatric study in $104 \mathrm{HCT}$ recipients found RVI to be a predictor of idiopathic pneumonia syndrome and BOS [37*]. Only one study has evaluated BOS prevalence and risk factors since $2005 \mathrm{NIH}$ consensus criteria were defined to 
standardize the diagnosis of BOS [38*]. In this analysis, the prevalence of BOS after HCT was higher using the new criteria definition, and there was no association with RVI [38*]. Additional investigation using the 2005 criteria will be necessary to further study whether RVI confers risk for the development of BOS.

\section{Solid organ transplantation}

Risk factors for disease progression have not been as well identified in solid organ transplant (SOT) recipients. Lung transplant recipients have the highest disease severity and long-term impact related to RVIs, but other organ transplant recipients may also have severe disease and complications. One study of RVIs in 152 SOT non-lung transplant recipients found the most complications among recipients of heart transplants $(27.5 \%)$, followed by liver (10.7\%) and kidney (7.8\%) [39**]. A total of 3.7\% of RVIs were complicated by pneumonia, and there was no relationship between infection and organ rejection [39**].

Table 2 provides an overview of recent relevant studies of RVIs in lung transplant recipients, highlighting short and long-term consequences. One study using Luminex technology to detect a respiratory virus in $14 \%$ of bronchoalveolar (BAL) samples from $52 \%$ of lung transplant recipients found an association between RVIs and acute rejection [42**]. Conversely, a similar study using PCR found a respiratory virus in $17 \%$ of BAL samples, but acute rejection was not associated with viral detection [46*]. However, detection of respiratory viruses in samples from patients with acute rejection was associated with worse lung function and slower recovery [46*]. Two retrospective pediatric studies showed no association between RVI and acute or chronic allograft rejection, but RVI was independently associated with decreased 1-year survival in one large multicenter cohort [43, $44 *]$. Thus far, a firm association has yet to be established between RVIs and either acute rejection or chronic allograft dysfunction after SOT, and large prospective studies with comprehensive viral testing and well-controlled multivariable models are needed to further evaluate these consequences.

\section{Newly discovered respiratory viruses}

With improved diagnostic methods, the significance of recently discovered respiratory viruses can be elucidated in the transplant population. Although viruses such as RSV and PIV are known to cause severe morbidity and mortality in immunosuppressed patients, we will limit discussion to recent updates regarding viruses that have been newly discovered or emerged in the last 10 years.

\section{Human metapneumovirus}

HMPV is most closely related to RSV and can cause both upper and severe lower respiratory tract infections after transplantation [49]. Asymptomatic shedding may potentially occur although this has not been consistently reported [50,51]. One prospective study found that $40 \%$ of HMPV infections in 22 adults with hematologic malignancies progressed from upper respiratory infection to pneumonia, with case-fatality close to $14 \%$ [9]. Other studies in HCT recipients have shown pneumonia rates of $28 \%$ and mortality rates of 0-4\% [19-21*]. Among 163 HCT recipients who underwent BAL for the work-up of pulmonary infiltrates, HMPV was detected in BAL samples from 5 of 163 (3\%) patients; 4 of the 5 died with acute respiratory failure highlighting the potential severity of HMPV pneumonia [52].

In SOT recipients, the impact of HMPV has been mainly examined after lung transplantation, although case reports of severe disease have been described following liver and renal transplantation [53-55]. HMPV infection has been found in 4-6\% of lung 
transplant recipients but prevalence may be higher during nosocomial outbreaks [48*, 56 , 57]. One study in the setting of a community outbreak identified HMPV in BAL samples from 9 of $26(35 \%)$ patients; clinical presentation varied from asymptomatic infection to severe disease [56]. Acute allograft rejection was more frequent in the HMPV-infected group than in the non HMPV-infected group (33\% vs. $6 \%$, respectively; $\mathrm{p}=0.0257)$; and overall mortality was also higher (33\% vs. $0 \%$, respectively; $\mathrm{p}<0.0025)$ [56]. Another prospective study found HMPV infection to be as frequent as RSV after lung transplantation, and to cause as much pneumonia and acute allograft dysfunction (63\% vs. $72 \%$, respectively), but only RSV was associated with chronic allograft dysfunction at 6 months [41]. Similarly, another group reported that 25\% of HMPV infections in lung transplant recipients were associated with acute allograft dysfunction compared with $88 \%$ for RSV [48*].

\section{Human Bocavirus}

$\mathrm{HBoV}$, a small DNA virus, is a member of the parvoviridae family that was discovered in 2005 from respiratory samples [58]. HBoV has been identified in respiratory, blood, saliva, and stool samples from symptomatic immunocompetent children [59-61].

Seroepidemiologic studies have shown $90 \%$ seropositivity by age 5 . Although some studies have reported that $\mathrm{HBoV}$ is more frequent in patients with respiratory symptoms than in asymptomatic individuals, the role of $\mathrm{HBoV}$ in respiratory illness remains controversial $\left[62^{* *}\right]$.

A number of reports describe disseminated $\mathrm{HBoV}$ infection in immunocompromised patients, with virus detection in many sample types, including nasopharyngeal aspirate, serum, feces, and urine [63-65*]. In some patients, significant co-pathogens were also present and the clinical relevance of $\mathrm{HBoV}$ detection is unclear $[63,66]$. Even detection of $\mathrm{HBoV}$ DNA in blood is of uncertain significance and appears to be not uncommon. In one study of 31 immuno-compromised children, HBoV DNA was detected in $2.6 \%$ of whole blood samples from 4 patients without respiratory symptoms [67]. Preliminary results of a large prospective study of HCT recipients found a day 100 cumulative incidence of $\mathrm{HBoV}$ detection in respiratory samples of $2.1 \%$ [26]. In this cohort, $\mathrm{HBoV}$ was also detected in 5 serum samples from 2 patients [26]. No patients had pneumonia or died, and respiratory symptoms were mild or absent when $\mathrm{HBoV}$ was detected, even in pediatric patients and when the quantity of viral shedding was high [26].

Fewer data are available regarding $\mathrm{HBoV}$ after SOT. In a study including 53 lung transplant recipients, 86 symptomatic and asymptomatic BALs were all negative for $\mathrm{HBoV}$; in another study, $\mathrm{HBoV}$ was detected in BAL samples from 4 of 66 adults with respiratory insufficiency after transplantation (2 HCT, 1 lung, 1 liver) [68, 69]. One large prospective study of lung transplant recipients found 5 nasopharyngeal swabs but none of the simultaneous BAL samples to be positive for $\mathrm{HBoV}$ [46*]. In summary, additional data are needed to determine whether HBOV plays a pathogenic role after hematopoietic or solid organ transplantation.

\section{Coronavirus}

HCoVs are RNA viruses, members of the coronaviridae family. HCoV 229E and OC43 have long been known to be agents of the common cold. HCoV NL63 and HKU1 were discovered in 2004, and are associated with upper and lower respiratory tract infections in infants and older adults [70,71].

Data on HCoVs in HCT recipients are limited. A recent report describes day 100 incidence for these 4 HCoVs of $11 \%$ (22 patients) among 215 allogeneic HCT recipients; 3 patients 
had prolonged shedding for more than 12 weeks [22**]. Interestingly, in this study, $\mathrm{HCoV}$ infection was not associated with the presence of respiratory symptoms. HCoV-NL63 was detected in a BAL sample from 1 patient who died of respiratory failure, who also had influenza A and HMPV detected simultaneously. Four cases of lower respiratory tract infections have been described including a fatal HCoV-NL63 infection in an adult HCT patient $\left[72,73^{*}, 74\right]$. Thus, HCoVs may occasionally cause lower respiratory tract disease after HCT, but the overall progression rate seems to be very low.

HCoVs have been identified in SOT recipients but clinical outcomes have not been specifically investigated. In a study of mostly hospitalized children with respiratory symptoms, 5 children with hematologic malignancies and one kidney transplant recipient had $\mathrm{HCoV}$ detected as the sole respiratory pathogen [75]. In a prospective study of 279 adults hospitalized for respiratory disease, BALs were tested for the 4 non-SARS HCoVs and found positive for 29 patients, 12 of whom received a lung transplant [76]. Most patients had no other identified etiology for their respiratory symptoms. Other studies of lung transplant recipients found $\mathrm{HCoVs}$ in $2-15 \%$ of samples but no specific analysis of symptoms or outcomes was performed [40, 42**, 46*]. Further study is needed to understand the pathogenesis of HCoVs and the immune response in immunosuppressed SOT recipients.

\section{Rhinovirus}

HRVs are RNA viruses and members of the picornaviridae family. They can be divided into 3 groups (A, B and recently described C) and further subdivided into $>100$ subtypes. The new HRV-C group has been associated with higher rates of pneumonia and more asthma exacerbations in children; however, others have found that the illness severity for HRV-C is comparable to that of HRV-A [77-79].

In HCT recipients, rhinovirus has been described as a possible cause of LRTI and was found in BALs from $8 \%$ of 77 patients, although each case had significant co-pathogens [80, 81]. Two fatal cases have been reported with mortality directly attributed to RHV infection [82]. Of 28 pediatric patients with hematologic malignancy or HCT infected with HRVs, only one, infected with HRV-C, died of respiratory insufficiency [83]. In a large prospective study of 215 allogeneic HCT recipients, HRV day 100 cumulative incidence was $22.3 \%$ (45 patients); $22 \%$ of HRV-infected patients had a concurrent second respiratory virus [22**]. Median duration of viral shedding was 3 weeks, but 6 patients shed HRV for more than 3 months. A positive HRV sample within the last week was significantly associated with multiple respiratory symptoms. Progression to LRTI was uncommon compared with other respiratory viruses, but 2 patients were positive for HRV in BAL and subsequently died $\left[22^{* *}\right]$.

A prospective study of 68 lung transplant recipients identified rhinovirus in BAL samples of $10(14.7 \%)$ patients. Three patients were reported with persistent RHV shedding over 12 months. All three had allograft dysfunction and two died [84]. Another study found an HRV incidence of $18 \%$ among 67 adult lung transplant recipients [83]. The presence of low HRV amounts in BAL was not associated with clinical symptoms, which by contrast were consistently observed in the presence of high viral load [83]. Studies are needed to investigate risk factors for HRV disease severity in transplant recipients, and particularly for associations with HRV-C infection.

\section{Human polyomaviruses, WU and KI}

KIPyV and WUPyV, two new human polyomaviruses were described simultaneously in 2007 , both detected from respiratory specimens $[85,86]$. Seroprevalence for children and 
adults is approximately $55-60 \%$ for both viruses, but no symptoms have yet been clearly associated with these viruses in the immunocompetent population [87].

Few data are available in transplant recipients, but it is suspected that these viruses establish latency, with reactivation under immunosuppression, similar to other polyomaviruses. In 31 HCT recipients with 126 serial nasopharyngeal aspirates, 2 samples were positive (one for each virus) without associated symptoms [28]. Another study reported a higher incidence of KiPyV of $17.8 \%$ in respiratory samples from $45 \mathrm{HCT}$ recipients with acute respiratory illness; WUPyV was not detected [27*]. Preliminary results of a prospective study of 196 HCT recipients found KIPyV and WUPyV in nasal wash samples in $18.4 \%$ and $7.1 \%$ of patients, respectively. Although some positive episodes lasted many weeks, and the viruses were detected in high copy numbers in some patients, detection was not associated with the presence of serious respiratory symptoms in this cohort [29].

In a cohort of 24 lung transplant recipients with 53 BAL samples, KIPyV and WUPyV were detected in $6(25 \%)$ and $7(29.2 \%)$ patients, respectively, all with 1 positive sample, and an association was observed between the presence of either virus and acute rejection [8*]. Whether these viruses are a trigger for rejection, or whether rejection episodes lead to virus reactivation, remains to be clarified. Further investigation is needed to determine the significance of these viruses following transplantation.

\section{Pandemic influenza $\mathrm{A} / \mathrm{H} 1 \mathrm{~N} 1$ and transplant recipients}

Since the emergence of the 2009 pandemic influenza A/H1N1 (pH1N1) strain, comparisons of virulence and transmissibility between seasonal H1N1 and pH1N1 in immunocompetent patients has not demonstrated significant differences [89-91]. In HCT recipients, the incidence of seasonal influenza has been reported between $1-4 \%$, and can be significantly higher in outbreak situations [5-7, 12, 13, 92**]. Pandemic H1N1 has been described in HCT recipients and oncology patients from several studies and case series (Table 3). Casefatality rates have ranged from 0 to $38 \%$ in various cohorts [95, 98-102, 104, 105].

Factors associated with severe disease included profound lymphopenia, increasing age, preexisting lung disease, bacterial co-infection, and delayed antivirals $>48$ hours after initial symptoms [93, 96, 114-119]. A recent study in HCT recipients found that, although there was no difference in mortality, pH1N1 infection was significantly associated with pneumonia, hypoxemia, and prolonged viral shedding compared with seasonal influenza A [93]. Importantly, in a multivariable model, even delayed administration of antivirals was shown to be protective in preventing pneumonia, and corticosteroids ( $\geq 1 \mathrm{mg} / \mathrm{kg}$ ) were associated with a reduced risk for mechanical ventilation [93]. One case report describing the detection of influenza RNA in plasma of a patient with respiratory failure suggests that this may be a biomarker for severe disease [114].

Table 3 highlights studies describing pH1N1 in SOT recipients. Many case reports have highlighted the varied severity of $\mathrm{pH} 1 \mathrm{~N} 1$ disease among specific solid organ recipients [120-125]. In general; death rates appear consistently lower for SOT than HCT recipients, although one report describes significant mortality after lung transplantation [110]. Delayed antiviral therapy ( $>48$ hours) and diabetes mellitus have been identified as risk factors for poor outcomes [108**, 112]. The largest SOT study included 237 patients from 26 centers with kidney, liver, lung, heart and other organ allograft transplantation [108**]. Adults had more risk of pneumonia and death than children, but children were significantly more likely than adults to receive antiviral therapy within 48 hours [108**]. In this study, complication rates were similar between lung and other organ transplant recipients. 


\section{Antiviral resistance and $\mathrm{pH} 1 \mathrm{~N} 1$}

Influenza resistance to antiviral drugs is an important epidemiologic and clinical concern $[31,126,127]$. Cases of resistant pH1N1 quickly emerged during the 2009 pandemic [128]. Nearly all resistant strains had the same H275Y substitution in the neuraminidase protein, and this mutation was observed to develop within 48 hours of exposure to oseltamivir [129-131*]. Although oseltamivir resistance rates were estimated as $<1 \%$ in the general population, resistance may have developed in up to half of HCT recipients, as indicated by studies in which serial positive influenza samples were tested and found to develop the $\mathrm{H} 275 \mathrm{Y}$ mutation after initiation of therapy $\left[105,132,133^{*}\right]$. A variety of outcomes among HCT recipients with oseltamivir-resistant $\mathrm{pH} 1 \mathrm{~N} 1$ have been described, from benign upper respiratory infection to severe and fatal pneumonia [133*]. Community and nosocomial transmission of $\mathrm{H} 275 \mathrm{Y}$-mutant $\mathrm{pH} 1 \mathrm{~N} 1$ has been described in immunocompetent and immunocompromised populations [134*, 135*].

\section{Conclusion}

Newly discovered respiratory viruses, such as HMPV, HBoV, and human polyomaviruses, and new viruses such as 2009 pandemic influenza A/H1N1, cause a spectrum of illness in patients after transplantation. With advancements in molecular diagnostics, data are rapidly emerging regarding the overall morbidity associated with these infections. HMPV appears to cause a similar spectrum of disease as RSV, with the potential for severe pneumonia. Recent studies suggest that lower respiratory tract disease appears to be uncommon, although possible, with coronavirus and rhinovirus, and even rarer with bocavirus and polyomavirus infections. Further study is needed to determine long-term sequelae of respiratory virus infections after transplantation, and to define the clinical manifestations associated with new viruses such as HBoV, KIPyV, and WUPyV. Delayed antiviral therapy and lymphopenia were consistently associated with severe disease from 2009 pH1N1, and pH1N1 seemed to cause increased disease severity compared with seasonal influenza A in HCT recipients. The development of oseltamivir-resistant $\mathrm{pH} 1 \mathrm{~N} 1$ in immunocompromised patients is of concern, and highlights the need for optimized management with early and aggressive therapy and close monitoring. Well-designed studies are essential to fully characterize the epidemiology and long-term sequelae of respiratory viruses so that treatment and prevention strategies can be developed for highly immunosuppressed transplant recipients.

\section{Acknowledgments}

We thank Dr. Michael Boeckh for critical review of this manuscript.

Financial support: This work was supported by NIH grants K23HL091059 and L40AI071572.

\section{References and recommended reading}

1. Krunic N, Yager TD, Himsworth D, et al. xTAG RVP assay: analytical and clinical performance. J Clin Virol. Nov; 2007 40(Suppl 1):S39-46. [PubMed: 18162254]

2*. Mahony JB. Nucleic acid amplification-based diagnosis of respiratory virus infections. Expert Rev Anti Infect Ther. Nov; 2010 8(11):1273-92. [PubMed: 21073292] [As molecular methods become standardized, nucleic acid amplification-based diagnosis of respiratory viruses is replacing traditional culture and antigenic assays. This review article describes the commercial molecular assays targeting respiratory viruses that are available and discusses the current and future roles of molecular diagnosis.]

3*. Kuypers J, Campbell AP, Cent A, et al. Comparison of conventional and molecular detection of respiratory viruses in hematopoietic cell transplant recipients. Study comparing real-time RTPCR with traditional virology for respiratory virus detection in nasal washes collected from 
hematopoietic stem cell transplant recipients. This study describes the higher sensitivity of RTPCR over viral culture and DFA. Transpl Infect Dis. Aug; 2009 11(4):298-303.

4*. Balada-Llasat JM, Larue H, Kelly C, et al. Evaluation of commercial ResPlex II v2.0, MultiCode((R))-PLx, and xTAG((R)) respiratory viral panels for the diagnosis of respiratory viral infections in adults. J Clin Virol. Nov 1.2010 [Comparative study of three commercial molecular assays targeting respiratory viruses. This is one of the first studies comparing those new assays and reporting similar sensitivity.]

5. Martino R, Porras RP, Rabella N, et al. Prospective study of the incidence, clinical eatures, and outcome of symptomatic upper and lower respiratory tract infections by respiratory viruses in adult recipients of hematopoietic stem cell transplants for hematologic malignancies. Biol Blood Marrow Transplant. Oct; 2005 11(10):781-96. [PubMed: 16182179]

6. Martino R, Ramila E, Rabella N, et al. Respiratory virus infections in adults with hematologic malignancies: a prospective study. Clin Infect Dis. Jan 1; 2003 36(1):1-8. [PubMed: 12491194]

7. Nichols WG, Guthrie KA, Corey L, Boeckh M. Influenza infections after hematopoietic stem cell transplantation: risk factors, mortality, and the effect of antiviral therapy. Clin Infect Dis. Nov 1; 2004 39(9):1300-6. [PubMed: 15494906]

8. Ljungman $\mathrm{P}$, Ward KN, Crooks BN, et al. Respiratory virus infections after stem cell transplantation: a prospective study from the Infectious Diseases Working Party of the European Group for Blood and Marrow Transplantation. Bone Marrow Transplant. Sep; 2001 28(5):479-84. [PubMed: 11593321]

9. Williams JV, Martino R, Rabella N, et al. A prospective study comparing human metapneumovirus with other respiratory viruses in adults with hematologic malignancies and respiratory tract infections. J Infect Dis. Sep 15; 2005 192(6):1061-5. [PubMed: 16107960]

$10 * *$. Peck AJ, Englund JA, Kuypers J, et al. Respiratory virus infection among hematopoietic cell transplant recipients: evidence for asymptomatic parainfluenza virus infection. Blood. Sep 1; 2007 110(5):1681-8. [PubMed: 17502457] [Large prospective longitudinal study in which nasal washes from a cohort of 157 hematopoietic stem cell transplant recipients were tested weekly for 100 days by real-time RT-PCR. This study provides accurate information on incidence of respiratory viruses and highlights the potential for asymptomatic infections.]

11. Chemaly RF, Ghosh S, Bodey GP, et al. Respiratory viral infections in adults with hematologic malignancies and human stem cell transplantation recipients: a retrospective study at a major cancer center. Medicine (Baltimore). Sep; 2006 85(5):278-87. [PubMed: 16974212]

12. Machado CM, Boas LS, Mendes AV, et al. Low mortality rates related to respiratory virus infections after bone marrow transplantation. Bone Marrow Transplant. Apr; 2003 31(8):695-700. [PubMed: 12692610]

13. Machado CM, Boas LS, Mendes AV, et al. Use of Oseltamivir to control influenza complications after bone marrow transplantation. Bone Marrow Transplant. Jul; 2004 34(2):111-4. [PubMed: 15094755]

14. Schiffer JT, Kirby K, Sandmaier B, et al. Timing and severity of community acquired respiratory virus infections after myeloablative versus non-myeloablative hematopoietic stem cell transplantation. Haematologica. Aug; 2009 94(8):1101-8. [PubMed: 19644142]

15. Nichols WG, Gooley T, Boeckh M. Community-acquired respiratory syncytial virus and parainfluenza virus infections after hematopoietic stem cell transplantation: the Fred Hutchinson Cancer Research Center experience. Biol Blood Marrow Transplant. 2001; 7(Suppl):11S-5S. [PubMed: 11777098]

16. Avetisyan G, Mattsson J, Sparrelid E, Ljungman P. Respiratory syncytial virus infection in recipients of allogeneic stem-cell transplantation: a retrospective study of the incidence, clinical features, and outcome. Transplantation. Nov 27; 2009 88(10):1222-6. [PubMed: 19935377]

17. Khanna N, Widmer AF, Decker M, et al. Respiratory syncytial virus infection in patients with hematological diseases: single-center study and review of the literature. Clin Infect Dis. Feb 1; 2008 46(3):402-12. [PubMed: 18181739]

18. Nichols WG, Corey L, Gooley T, et al. Parainfluenza virus infections after hematopoietic stem cell transplantation: risk factors, response to antiviral therapy, and effect on transplant outcome. Blood. Aug 1; 2001 98(3):573-8. [PubMed: 11468152] 
19. Oliveira R, Machado A, Tateno A, et al. Frequency of human metapneumovirus infection in hematopoietic SCT recipients during 3 consecutive years. Bone Marrow Transplant. Aug; 2008 42(4):265-9. [PubMed: 18516078]

20. Kamboj M, Gerbin M, Huang CK, et al. Clinical characterization of human metapneumovirus infection among patients with cancer. J Infect. Dec; 2008 57(6):464-71. [PubMed: 19027169]

21*. Debur MC, Vidal LR, Stroparo E, et al. Human metapneumovirus infection in hematopoietic stem cell transplant recipients. Transpl Infect Dis. Apr; 2009 12(2):173-9. [PubMed: 19878491] [Most recent retrospective study describing human metapneumovirus infection in hematopoietic stem cell transplant recipients. Five of $18(27.8 \%)$ patients developed lower respiratory tract infection.]

22**. Milano F, Campbell AP, Guthrie KA, et al. Human rhinovirus and coronavirus detection among allogeneic hematopoietic stem cell transplantation recipients. Blood. Mar 11; 2010 115(10): 2088-94. [PubMed: 20042728] [Large prospective longitudinal study reporting the incidence of human rhinovirus and human coronavirus among hematopoietic stem cell transplant recipients. Description of incidence, viral shedding, and outcomes, as well as multivariable analysis of respiratory and systemic symptoms are provided.]

23. Runde V, Ross S, Trenschel R, et al. Adenoviral infection after allogeneic stem cell transplantation (SCT): report on 130 patients from a single SCT unit involved in a prospective multi center surveillance study. Bone Marrow Transplant. Jul; 2001 28(1):51-7. [PubMed: 11498744]

24. Muller A, Klinkenberg D, Vehreschild J, et al. Low prevalence of human metapneumovirus and human bocavirus in adult immunocompromised high risk patients suspected to suffer from Pneumocystis pneumonia. J Infect. Mar; 2009 58(3):227-31. [PubMed: 19211148]

25. Garbino J, Soccal PM, Aubert JD, et al. Respiratory viruses in bronchoalveolar lavage: a hospitalbased cohort study in adults. Thorax. May; 2009 64(5):399-404. [PubMed: 19174425]

26. Peck Campbell, A.; Kuypers, J.; Nguyen, P., et al. Human Bocavirus (BoV) Detection in Nasal Washes of Hematopoietic Cell Transplantation Recipients.. Slide presentation at the 48th ICAAC/ 46th IDSA Annual Meeting; Washington DC. October 28, 2008; (Abstract V-3777)

27*. Mourez T, Bergeron A, Ribaud P, et al. Polyomaviruses KI and WU in immunocompromised patients with respiratory disease. Emerg Infect Dis. Jan; 2009 15(1):107-9. [PubMed: 19116066] [Study providing evidence of significant presence of KIPyV in respiratory tract samples from hematopoietic stem cell transplant recipients.]

28. Debiaggi M, Canducci F, Brerra R, et al. Molecular epidemiology of KI and WU polyomaviruses in infants with acute respiratory disease and in adult hematopoietic stem cell transplant recipients. J Med Virol. Jan; 2010 82(1):153-6. [PubMed: 19950241]

29. Kuypers, J.; Peck Campbell, A.; Wright, N., et al. Detection of WUV and KIV Polyomaviruses in Nasal Wash Specimens from Hematopoietic Cell Transplant Recipients.. Poster presentation at the 48th ICAAC/46th IDSA Annual Meeting; Washington DC. October 27, 2008; (Abstract V-1642)

30. Boudreault AA, Xie H, Leisenring W, et al. Impact of Corticosteroid Treatment and Antiviral Therapy on Clinical Outcomes in Hematopoietic Cell Transplant Patients Infected with Influenza Virus. Biol Blood Marrow Transplant. Sep 23.2010

31. Gooskens J, Jonges M, Claas EC, et al. Prolonged influenza virus infection during lymphocytopenia and frequent detection of drug-resistant viruses. J Infect Dis. May 15; 2009 199(10):1435-41. [PubMed: 19392620]

32. Gooskens J, Jonges M, Claas EC, et al. Morbidity and mortality associated with nosocomial transmission of oseltamivir-resistant influenza A(H1N1) virus. JAMA. Mar 11; 2009 301(10): 1042-6. [PubMed: 19255111]

33. Nichols WG, Erdman DD, Han A, et al. Prolonged outbreak of human parainfluenza virus 3 infection in a stem cell transplant outpatient department: insights from molecular epidemiologic analysis. Biol Blood Marrow Transplant. Jan; 2004 10(1):58-64. [PubMed: 14752780]

34. Erard V, Chien JW, Kim HW, et al. Airflow decline after myeloablative allogeneic hematopoietic cell transplantation: the role of community respiratory viruses. J Infect Dis. Jun 15; 2006 193(12): 1619-25. [PubMed: 16703503]

35*. Chien JW, Duncan S, Williams KM, Pavletic SZ. Bronchiolitis obliterans syndrome after allogeneic hematopoietic stem cell transplantation-an increasingly recognized manifestation of 
chronic graft-versus-host disease. Biol Blood Marrow Transplant. Jan; 2010 16(1 Suppl):S10614. [PubMed: 19896545] [Review article describing risk factors and outcomes of bronchiolitis obliterans after allogeneic hematopoietic stem cell transplantation.]

36. Chien JW, Martin PJ, Gooley TA, et al. Airflow obstruction after myeloablative allogeneic hematopoietic stem cell transplantation. Am J Respir Crit Care Med. Jul 15; 2003 168(2):208-14. [PubMed: 12649126]

37*. Versluys AB, Rossen JW, van Ewijk B, et al. Strong association between respiratory viral infection early after hematopoietic stem cell transplantation and the development of lifethreatening acute and chronic alloimmune lung syndromes. Biol Blood Marrow Transplant. Jun; 2010 16(6):782-91. [PubMed: 20060053] [Prospective pediatric study showing that respiratory viral infection early after hematopoietic stem cell transplantation is a risk factor for alloimmune lung syndrome including idiopathic pneumonia syndrome, bronchiolitis obliterans, and bronchiolitis obliterans organizing pneumonia.]

38*. Au BK, Au MA, Chien JW. Bronchiolitis Obliterans Syndrome Epidemiology After Allogeneic Hematopoietic Cell Transplantation. Biol Blood Marrow Transplant. Nov 30.2010 [First study describing the absence of association between respiratory viral infection and bronchiolitis obliterans in hematopoietic stem cell transplant recipients using the new 2005 NIH definition of bronchiolitis obliterans syndrome.]

39**. Lopez-Medrano F, Aguado JM, Lizasoain M, et al. Clinical implications of respiratory virus infections in solid organ transplant recipients: a prospective study. Transplantation. Oct 15; 2007 84(7):851-6. [PubMed: 17984837] [Large study looking at respiratory virus infections in solid organ transplant recipients other than lung transplant recipients. This study reports high rates of complications in heart transplants (27.5\%), followed by liver (10.7\%) and kidney (7.8\%) but no relationship with organ rejection.]

40. Gottlieb J, Schulz TF, Welte T, et al. Community-acquired respiratory viral infections in lung transplant recipients: a single season cohort study. Transplantation. May 27; 2009 87(10):1530-7. [PubMed: 19461490]

41. Hopkins P, McNeil K, Kermeen F, et al. Human metapneumovirus in lung transplant recipients and comparison to respiratory syncytial virus. Am J Respir Crit Care Med. Oct 15; 2008 178(8):87681. [PubMed: 18658110]

$42 * *$. Kumar D, Husain S, Chen MH, et al. A prospective molecular surveillance study evaluating the clinical impact of community-acquired respiratory viruses in lung transplant recipients. Transplantation. Apr 27; 2010 89(8):1028-33. [PubMed: 20075787] [Large prospective study in 93 adult lung transplant recipients using sensitive molecular methods to test BAL samples and showing that respiratory virus infections were associated wtih biopsy-proven acute allograft rejection. No difference in outcome was seen between patients that had symptomatic and asymptomatic respiratory virus infections.]

43. Liu M, Worley S, Arrigain S, et al. Respiratory viral infections within one year after pediatric lung transplant. Transpl Infect Dis. Aug; 2009 11(4):304-12. [PubMed: 19422670]

44*. Liu M, Mallory GB, Schecter MG, et al. Long-term impact of respiratory viral infection after pediatric lung transplantation. Pediatr Transplant. May; 2010 14(3):431-6. [PubMed: 20214745] [Retrospective study in pediatric lung transplant recipients describing no association between respiratory virus infection and chronic allograft rejection.]

45. Milstone AP, Brumble LM, Barnes J, et al. A single-season prospective study of respiratory viral infections in lung transplant recipients. Eur Respir J. Jul; 2006 28(1):131-7. [PubMed: 16510454]

46*. Soccal PM, Aubert JD, Bridevaux PO, et al. Upper and lower respiratory tract viral infections and acute graft rejection in lung transplant recipients. Clin Infect Dis. Jul 15; 2010 51(2):163-70. [PubMed: 20524853] [Prospective study in adult lung transplant recipients in which no association was found between respiratory virus infection and biopsy-proven acute allograft rejection.]

47. Vilchez RA, McCurry K, Dauber J, et al. The epidemiology of parainfluenza virus infection in lung transplant recipients. Clin Infect Dis. Dec 15; 2001 33(12):2004-8. [PubMed: 11702289]

48*. Weinberg A, Lyu DM, Li S, et al. Incidence and morbidity of human metapneumovirus and other community-acquired respiratory viruses in lung transplant recipients. Transpl Infect Dis. Aug 1; 2010 12(4):330-5. [PubMed: 20456714] [Prospective study in adult lung transplant recipients 
describing the incidence and the impact of human metapneumovirus infection on acute and chronic graft rejection.]

49. van den Hoogen BG, de Jong JC, Groen J, et al. A newly discovered human pneumovirus isolated from young children with respiratory tract disease. Nat Med. Jun; 2001 7(6):719-24. [PubMed: 11385510]

50. Debiaggi M, Canducci F, Sampaolo M, et al. Persistent symptomless human metapneumovirus infection in hematopoietic stem cell transplant recipients. J Infect Dis. Aug 15; 2006 194(4):4748. [PubMed: 16845630]

51. Debiaggi M, Canducci F, Terulla C, et al. Long-term study on symptomless human metapneumovirus infection in hematopoietic stem cell transplant recipients. New Microbiol. Jul; 2007 30(3):255-8. [PubMed: 17802904]

52. Englund JA, Boeckh M, Kuypers J, et al. Brief communication: fatal human metapneumovirus infection in stem-cell transplant recipients. Ann Intern Med. Mar 7; 2006 144(5):344-9. [PubMed: 16520475]

53. Evashuk KM, Forgie SE, Gilmour S, et al. Respiratory failure associated with human metapneumovirus infection in an infant posthepatic transplant. Am J Transplant. Jul; 2008 8(7): 1567-9. [PubMed: 18513273]

54. Richards A, Chuen JN, Taylor C, et al. Acute respiratory infection in a renal transplant recipient. Nephrol Dial Transplant. Dec; 2005 20(12):2848-50. [PubMed: 16221714]

55. Raza K, Ismailjee SB, Crespo M, et al. Successful outcome of human metapneumovirus (hMPV) pneumonia in a lung transplant recipient treated with intravenous ribavirin. J Heart Lung Transplant. Aug; 2007 26(8):862-4. [PubMed: 17692793]

56. Larcher C, Geltner C, Fischer H, et al. Human metapneumovirus infection in lung transplant recipients: clinical presentation and epidemiology. J Heart Lung Transplant. Nov; 2005 24(11): 1891-901. [PubMed: 16297797]

57. Dare R, Sanghavi S, Bullotta A, et al. Diagnosis of human metapneumovirus infection in immunosuppressed lung transplant recipients and children evaluated for pertussis. J Clin Microbiol. Feb; 2007 45(2):548-52. [PubMed: 17065270]

58. Allander T, Tammi MT, Eriksson M, et al. Cloning of a human parvovirus by molecular screening of respiratory tract samples. Proc Natl Acad Sci U S A. Sep 6; 2005 102(36):12891-6. [PubMed: 16118271]

59. Allander T, Jartti T, Gupta S, et al. Human bocavirus and acute wheezing in children. Clin Infect Dis. Apr 1; 2007 44(7):904-10. [PubMed: 17342639]

60. Bastien N, Brandt K, Dust K, et al. Human Bocavirus infection, Canada. Emerg Infect Dis. May; 2006 12(5):848-50. [PubMed: 16704852]

61. Martin ET, Taylor J, Kuypers J, et al. Detection of bocavirus in saliva of children with and without respiratory illness. J Clin Microbiol. Dec; 2009 47(12):4131-2. [PubMed: 19794045]

62**. Schildgen O, Muller A, Allander T, et al. Human bocavirus: passenger or pathogen in acute respiratory tract infections? Clin Microbiol Rev. Apr; 2008 21(2):291-304. [PubMed: 18400798] [Comprehensive review of human bocavirus discovery, biology and epidemiology.This article analyzes all studies showing associations between human bocavirus infection and symptoms in immunocompetent patients. The role of human bocavirus as a pathogen is extensively discussed.]

63. Schenk T, Strahm B, Kontny U, et al. Disseminated bocavirus infection after stem cell transplant. Emerg Infect Dis. Sep; 2007 13(9):1425-7. [PubMed: 18252130]

64. Kainulainen L, Waris M, Soderlund-Venermo M, et al. Hepatitis and human bocavirus primary infection in a child with T-cell deficiency. J Clin Microbiol. Dec; 2008 46(12):4104-5. [PubMed: 18842946]

65*. de Vries JJ, Bredius RG, van Rheenen PF, et al. Human bocavirus in an immunocompromised child presenting with severe diarrhea. J Clin Microbiol. Apr; 2009 47(4):1241-3. [PubMed: 19193836] [Description of severe bocavirus infection in a severely immunocompromised child with a review of similar cases reported in the literature.]

66. Schenk T, Maier B, Hufnagel M, et al. Persistence of Human Bocavirus DNA in Immunocompromised Children. Pediatr Infect Dis J. Aug 24.2010 
67. Tozer SJ, Lambert SB, Whiley DM, et al. Detection of human bocavirus in respiratory, fecal, and blood samples by real-time PCR. J Med Virol. Mar; 2009 81(3):488-93. [PubMed: 19152414]

68. Miyakis S, van Hal SJ, Barratt J, et al. Absence of human Bocavirus in bronchoalveolar lavage fluid of lung transplant patients. J Clin Virol. Feb; 2009 44(2):179-80. [PubMed: 19083266]

69. Costa C, Bergallo M, Cavallo R. Detection of Human Bocavirus in bronchoalveolar lavage from Italian adult patients. J Clin Virol. May; 2009 45(1):81-2. [PubMed: 19324589]

70. Fouchier RA, Hartwig NG, Bestebroer TM, et al. A previously undescribed coronavirus associated with respiratory disease in humans. Proc Natl Acad Sci U S A. Apr 20; 2004 101(16):6212-6. [PubMed: 15073334]

71. van der Hoek L, Pyrc K, Jebbink MF, et al. Identification of a new human coronavirus. Nat Med. Apr; 2004 10(4):368-73. [PubMed: 15034574]

72. Pene F, Merlat A, Vabret A, et al. Coronavirus 229E-related pneumonia in immunocompromised patients. Clin Infect Dis. Oct 1; 2003 37(7):929-32. [PubMed: 13130404]

73*. Oosterhof L, Christensen CB, Sengelov H. Fatal lower respiratory tract disease with human corona virus NL63 in an adult haematopoietic cell transplant recipient. Bone Marrow Transplant. Jun; 2010 45(6):1115-6. [PubMed: 19820731] [Case report of human coronavirus pneumonia in an adult hematopoietic stem cell transplant recipient, highlighting the potential for severe disease.]

74. Folz RJ, Elkordy MA. Coronavirus pneumonia following autologous bone marrow transplantation for breast cancer. Chest. Mar; 1999 115(3):901-5. [PubMed: 10084516]

75. Kuypers J, Martin ET, Heugel J, et al. Clinical disease in children associated with newly described coronavirus subtypes. Pediatrics. Jan; 2007 119(1):e70-6. [PubMed: 17130280]

76. Garbino J, Crespo S, Aubert JD, et al. A prospective hospital-based study of the clinical impact of non-severe acute respiratory syndrome (Non-SARS)-related human coronavirus infection. Clin Infect Dis. Oct 15; 2006 43(8):1009-15. [PubMed: 16983613]

77. Piralla A, Rovida F, Campanini G, et al. Clinical severity and molecular typing of human rhinovirus $\mathrm{C}$ strains during a fall outbreak affecting hospitalized patients. J Clin Virol. Aug; 2009 45(4):311-7. [PubMed: 19473873]

78. Lau SK, Yip CC, Tsoi HW, et al. Clinical features and complete genome characterization of a distinct human rhinovirus (HRV) genetic cluster, probably representing a previously undetected HRV species, HRV-C, associated with acute respiratory illness in children. J Clin Microbiol. Nov; 2007 45(11):3655-64. [PubMed: 17804649]

79. Xiang Z, Gonzalez R, Xie Z, et al. Human rhinovirus C infections mirror those of human rhinovirus A in children with community-acquired pneumonia. J Clin Virol. Oct; 2010 49(2):94-9. [PubMed: 20728404]

80. Ison MG, Hayden FG, Kaiser L, et al. Rhinovirus infections in hematopoietic stem cell transplant recipients with pneumonia. Clin Infect Dis. May 1; 2003 36(9):1139-43. [PubMed: 12715308]

81. Parody R, Rabella N, Martino R, et al. Upper and lower respiratory tract infections by human enterovirus and rhinovirus in adult patients with hematological malignancies. Am J Hematol. Sep; 2007 82(9):807-11. [PubMed: 17563077]

82. Gutman JA, Peck AJ, Kuypers J, Boeckh M. Rhinovirus as a cause of fatal lower respiratory tract infection in adult stem cell transplantation patients: a report of two cases. Bone Marrow Transplant. Oct; 2007 40(8):809-11. [PubMed: 17704788]

83. Gerna G, Piralla A, Rovida F, et al. Correlation of rhinovirus load in the respiratory tract and clinical symptoms in hospitalized immunocompetent and immunocompromised patients. J Med Virol. Aug; 2009 81(8):1498-507. [PubMed: 19551831]

84. Kaiser L, Aubert JD, Pache JC, et al. Chronic rhinoviral infection in lung transplant recipients. Am J Respir Crit Care Med. Dec 15; 2006 174(12):1392-9. [PubMed: 17008640]

85. Allander T, Andreasson K, Gupta S, et al. Identification of a third human polyomavirus. J Virol. Apr; 2007 81(8):4130-6. [PubMed: 17287263]

86. Gaynor AM, Nissen MD, Whiley DM, et al. Identification of a novel polyomavirus from patients with acute respiratory tract infections. PLoS Pathog. May 4.2007 3(5):e64. [PubMed: 17480120] 
87. Dalianis T, Ramqvist T, Andreasson K, et al. KI, WU and Merkel cell polyomaviruses: a new era for human polyomavirus research. Semin Cancer Biol. Aug; 2009 19(4):270-5. [PubMed: 19416753]

88*. Astegiano S, Bergallo M, Solidoro P, et al. Prevalence and clinical impact of olyomaviruses KI and WU in lung transplant recipients. Transplant Proc. May; 2010 42(4):1275-8. [PubMed: 20534279] [Study showing the presence of KIPyV and WUPyV in a significant proportion of lung transplant recipients. This study also reports the association between the presence of polyomavirus in the lungs and acute allograft dysfunction.]

89. Cowling BJ, Chan KH, Fang VJ, et al. Comparative epidemiology of pandemic and seasonal influenza A in households. N Engl J Med. Jun 10; 2010 362(23):2175-84. [PubMed: 20558368]

90. Belongia EA, Irving SA, Waring SC, et al. Clinical characteristics and 30-day outcomes for influenza A 2009 (H1N1), 2008-2009 (H1N1), and 2007-2008 (H3N2) infections. JAMA. Sep 8; 2010 304(10):1091-8. [PubMed: 20823435]

91. Shiley KT, Nadolski G, Mickus T, et al. Differences in the epidemiological characteristics and clinical outcomes of pandemic (H1N1) 2009 influenza, compared with seasonal influenza. Infect Control Hosp Epidemiol. Jul; 2010 31(7):676-82. [PubMed: 20500086]

$92 * *$. Kunisaki KM, Janoff EN. Influenza in immunosuppressed populations: a review of infection frequency, morbidity, mortality, and vaccine responses. Lancet Infect Dis. Aug; 2009 9(8):493504. [PubMed: 19628174] [Comprehensive review of influenza infection in immunocompromised populations including transplantation recipients and HIV patients. Extensive discussion regarding the immune response to influenza vaccine and challenges surrounding influenza vacccination.]

93. Choi S-M, Boudreault AA, Xie H, et al. Differences in Clinical Outcomes Following 2009 influenza A/H1N1 and Seasonal influenza Among Hematopoietic Cell Transplant Recipients. Blood. 2011 (in press).

94. Ditschkowski M, Elmaagacli AH, Beelen DW. H1N1 in allogeneic stem cell recipients: courses of infection and influence of vaccination on graft-versus-host-disease (GVHD). Ann Hematol. Jan; 2011 90(1):117-8. [PubMed: 20432037]

95. George B, Ferguson P, Kerridge I, et al. The clinical impact of infection with Swine flu (H1N1 09) strain of influenza virus in hematopoietic stem cell transplant recipients. Biol Blood Marrow Transplant. Jul 14.2010

96. Protheroe RE, Kirkland KE, Pearce RM, et al. The clinical features and outcome of 2009 H1N1 influenza infection in Allo-SCT patients: a British Society of Blood and Marrow Transplantation study. Bone Marrow Transplant. Feb 28.2011

97. Rihani R, Hayajneh W, Sultan I, et al. Infections with the 2009 H1N1 influenza virus among hematopoietic SCT recipients: a single center experience. Bone Marrow Transplant. Jan 17.2011

98. Taplitz R, Espinosa-Aguilar L, Green J, et al. Novel H1N1 Influenza In Hematopoietic Stem Cell Transplant Recipients: Two Center's Experience. Biol Blood Marrow Transplant. Aug 10.2010

99. Caselli D, Carraro F, Castagnola E, et al. Morbidity of pandemic H1N1 influenza in children with cancer. Pediatr Blood Cancer. Aug; 2010 55(2):226-8. [PubMed: 20582951]

100. Cost C, Brock E, Adams-Huet B, et al. 2009 pandemic influenza a (H1N1) virus infection in pediatric oncology and hematopoietic stem cell transplantation patients. Pediatr Blood Cancer. Oct 22.2010

101. Garland P, de Lavallade H, Sekine T, et al. Humoral and cellular immunity to primary H1N1 infection in patients with hematological malignancies and following stem cell transplantation. Biol Blood Marrow Transplant. Aug 10.2010

102. Lalayanni C, Sirigou A, Iskas M, et al. Outbreak of novel influenza A (H1N1) in an adult haematology department and haematopoietic cell transplantation unit: clinical presentation and outcome. J Infect. Sep; 2010 61(3):270-2. [PubMed: 20600296]

103. Liu C, Schwartz BS, Vallabhaneni S, et al. Pandemic (H1N1) 2009 infection in patients with hematologic malignancy. Emerg Infect Dis. Dec; 2010 16(12):1910-7. [PubMed: 21122221]

104. Redelman-Sidi G, Sepkowitz KA, Huang CK, et al. 2009 H1N1 influenza infection in cancer patients and hematopoietic stem cell transplant recipients. J Infect. Apr; 2010 60(4):257-63. [PubMed: 20138188] 
105. Tramontana AR, George B, Hurt AC, et al. Oseltamivir resistance in adult oncology and hematology patients infected with pandemic (H1N1) 2009 virus, Australia. Emerg Infect Dis. Jul; 2010 16(7):1068-75. [PubMed: 20587176]

106. Vigil, KJ.; Adachi, JA.; Jiang, Y., et al. Novel Influenza A (2009/H1N1) Infection In Patients with Hematological Malignancies During the 2009 Pandemic Outbreak: Early Antiviral Treatment Improves Survival.. Poster presentation at the 52nd ASH Annual Meeting and Exposition; Orlando, FL. December 4-7, 2010; (Abstract I-1731). 2010

107. Fox BD, Raviv Y, Rozengarten D, et al. Pandemic influenza (H1N1): impact on lung transplant recipients and candidates. J Heart Lung Transplant. Sep; 2010 29(9):1034-8. [PubMed: 20558087]

108**. Kumar D, Michaels MG, Morris MI, et al. Outcomes from pandemic influenza A H1N1 infection in recipients of solid-organ transplants: a multicentre cohort study. Lancet Infect Dis. Aug; 2010 10(8):521-6. [PubMed: 20620116] [Large prospective multicenter study of 2009 pandemic influenza A H1N1 in solid organ transplant recipients. This study reports a risk of lower respiratory tract infection in $32 \%$ of patients with pandemic H1N1, with adults being significantly more at risk of death compared with children.]

109. Low CY, Kee T, Chan KP, et al. Pandemic (H1N1) 2009 infection in adult solid organ transplant recipients in Singapore. Transplantation. Nov 15; 2010 90(9):1016-21. [PubMed: 20814355]

110. Ng BJ, Glanville AR, Snell G, et al. The Impact of Pandemic Influenza A H1N1 2009 on Australian Lung Transplant Recipients. Am J Transplant. Mar; 2011 11(3):568-74. [PubMed: 21299829]

111. Ridao-Cano N, Sanchez-Fructuoso AI, Rodriguez-Moreno A, Barrientos A. H1N1 2009 influenza in kidney transplant patients. Transplantation. Jul 27; 2010 90(2):224-5. [PubMed: 20644457]

112. Smud A, Nagel CB, Madsen E, et al. Pandemic Influenza A/H1N1 Virus Infection in Solid Organ Transplant Recipients: A Multicenter Study. Transplantation. Oct 1.2010

113. Vazquez-Alvarez Mdel C, Medrano-Lopez C, Camino-Lopez M. H1N1 influenza vaccination and infection in pediatric heart transplants. J Heart Lung Transplant. Nov.2010 29(11):1318. [PubMed: 20822923]

114. Campbell AP, Jacob ST, Kuypers J, et al. Respiratory failure caused by 2009 novel influenza A/ H1N1 in a hematopoietic stem-cell transplant recipient: Detection of extrapulmonary H1N1 RNA and use of intravenous peramivir. Ann Intern Med. May 4; 2010 152(9):619-20. [PubMed: 20439588]

115. Renaud C, Pergam SA, Polyak C, et al. Early emergence of an H275Y mutation in a hematopoietic cell transplant recipient treated with intravenous peramivir. Transpl Infect Dis. Nov 10.2010

116. Hajjar LA, Mauad T, Galas FR, et al. Severe novel influenza A (H1N1) infection in cancer patients. Ann Oncol. May 28.2010

117. Dulek DE, Williams JV, Creech CB, et al. Use of intravenous zanamivir after development of oseltamivir resistance in a critically Ill immunosuppressed child infected with 2009 pandemic influenza A (H1N1) virus. Clin Infect Dis. Jun 1; 2010 50(11):1493-6. [PubMed: 20415572]

118. Gaur AH, Bagga B, Barman S, et al. Intravenous zanamivir for oseltamivir-resistant 2009 H1N1 influenza. N Engl J Med. Jan 7; 2010 362(1):88-9. [PubMed: 20032317]

119. Rozovski U, Herishanu Y, Gipstein L, Naparstek E. Fatal H1N1 influenza infection in an alloSCT recipient. Bone Marrow Transplant. Oct; 2010 45(10):1572-3. [PubMed: 20098457]

120. Speers DJ, Williams SH, Pinder M, et al. Oseltamivir-resistant pandemic (H1N1) 2009 influenza in a severely ill patient: the first Australian case. Med J Aust. Feb 1; 2010 192(3):166-8. [PubMed: 20121687]

121. Garofano R, Rodriguez MA, Prados MC, et al. Cases of swine flu in kidney transplant recipients in our hospital. Transplant Proc. Oct; 2010 42(8):3141-2. [PubMed: 20970630]

121. Dohna-Schwake C, Schweiger B, Felderhoff-Muser U, et al. Severe H1N1 infection in a pediatric liver transplant recipient treated with intravenous zanamivir: efficiency and complications. Transplantation. Jul 27; 2010 90(2):223-4. [PubMed: 20644456] 
123. Anraku M, Husain S, Mazulli T, Pierre AF. Peri-operative novel 2009 H1N1 influenza virus infection successfully treated with oseltamivir and zanamivir in a lung transplant recipient. J Heart Lung Transplant. Nov 18.2010

124. Zapata R, Uribe M, Martinez W, et al. Severe novel H1N1 influenza A infection in the immediate postoperative period of a liver transplant patient. Liver Transpl. Apr; 2010 16(4):447-52. [PubMed: 20205234]

125. Al Aklabi MM, Weinkauf JG, Humar A, Ghorpade N. Successful bilateral lung transplantation in a patient with end-stage lung disease and positive novel influenza virus (H1N1). J Heart Lung Transplant. Aug; 2010 29(8):898-9. [PubMed: 20538489]

126. Weinstock DM, Gubareva LV, Zuccotti G. Prolonged shedding of multidrug-resistant influenza A virus in an immunocompromised patient. N Engl J Med. Feb 27; 2003 348(9):867-8. [PubMed: 12606750]

127. Carr S, Ilyushina NA, Franks J, et al. Oseltamivir-resistant Influenza A and B Viruses Pre- and Postantiviral Therapy in Children and Young Adults With Cancer. Pediatr Infect Dis J. Nov 2.2010

128. Oseltamivir-resistant novel influenza A. (H1N1) virus infection in two immunosuppressed patients - Seattle, Washington, 2009. MMWR Morb Mortal Wkly Rep. Aug 21; 2009 58(32): 893-6. [PubMed: 19696719]

129. Renaud C, Kuypers J, Corey L. Diagnostic accuracy of an allele-specific reverse transcriptasePCR assay targeting the $\mathrm{H} 275 \mathrm{Y}$ oseltamivir resistant mutation in 2009 pandemic influenza A/ H1N1 virus. J Clin Virol. Jul 29.2010

130. Deyde VM, Gubareva LV. Influenza genome analysis using pyrosequencing method: current applications for a moving target. Expert Rev Mol Diagn. Jul; 2009 9(5):493-509. [PubMed: 19580433]

131*. Inoue M, Barkham T, Leo YS, et al. Emergence of oseltamivir-resistant pandemic (H1N1) 2009 virus within 48 hours. Emerg Infect Dis. Oct; 2010 16(10):1633-6. [PubMed: 20875299] [Description of $\mathrm{H} 275 \mathrm{Y}$ mutation emerging as early as 48 hours after exposure to oseltamivir.]

132. Harvala H, Gunson R, Simmonds P, et al. The emergence of oseltamivir-resistant pandemic influenza A(H1N1) 2009 virus amongst hospitalised immunocompromised patients in Scotland, November-December, 2009. Euro Surveill. 2010; 15(14)

133*. Renaud C, Boudreault AA, Kuypers J, et al. Clinical characteristics and viral kinetics of H275Y mutant pandemic H1N1 2009 influenza in immunocompromised patients. . Emerg Infect Dis. 2011 (in press). [Larger case series of oseltamivir-resistant pandemic H1N1 in immunocompromised patients. Description of symptoms and outcome for each patient is provided.]

134*. Le QM, Wertheim HF, Tran ND, et al. A community cluster of oseltamivir-resistant cases of 2009 H1N1 influenza. N Engl J Med. Jan 7; 2010 362(1):86-7. [PubMed: 20007549] [First description of transmissibility of oseltamivir-resistant pandemic H1N1 in an immunocompetent population. All patients recovered without any complication.]

135*. Chen LF, Dailey NJ, Rao AK, et al. Cluster of Oseltamivir-Resistant 2009 Pandemic Influenza A (H1N1) Virus Infections on a Hospital Ward among Immunocompromised Patients--North Carolina, 2009. J Infect Dis. Mar; 2011 203(6):838-46. [PubMed: 21343149] [Description of oseltamivir-resistant pandemic H1N1 influenza outbreak among immunocompromised patients. All 4 patients died; death was directly related to H1N1 infection for 2 patients.]

Curr Opin Infect Dis. Author manuscript; available in PMC 2011 November 07. 


\section{Key points}

- New molecular diagnostic assays greatly improve our understanding of the impact of respiratory virus infections in hematopoietic stem cell and solid organ transplant recipients.

- Human metapneumovirus infections have similar outcomes to RSV infection in hematopoietic stem cell transplant recipients, including potentially severe and fatal pneumonia.

- Rhinovirus and coronavirus infections are very frequent in transplant recipients; lower respiratory tract disease can occasionally occur but is uncommon.

- Human bocavirus and the new human polyomaviruses, WUPyV and KiPyV, are present in the respiratory tract of transplant recipients but their significance in respiratory illness and overall clinical impact are still unknown.

- Pandemic H1N1 has the potential for rapid emergence of oseltamivir resistance, and is associated with significant morbidity in highly immunocompromised transplant recipients, particularly in patients with lymphopenia and delayed antiviral therapy.

- The association between respiratory virus infections and acute or chronic allograft rejection in lung transplant recipients remains controversial. 


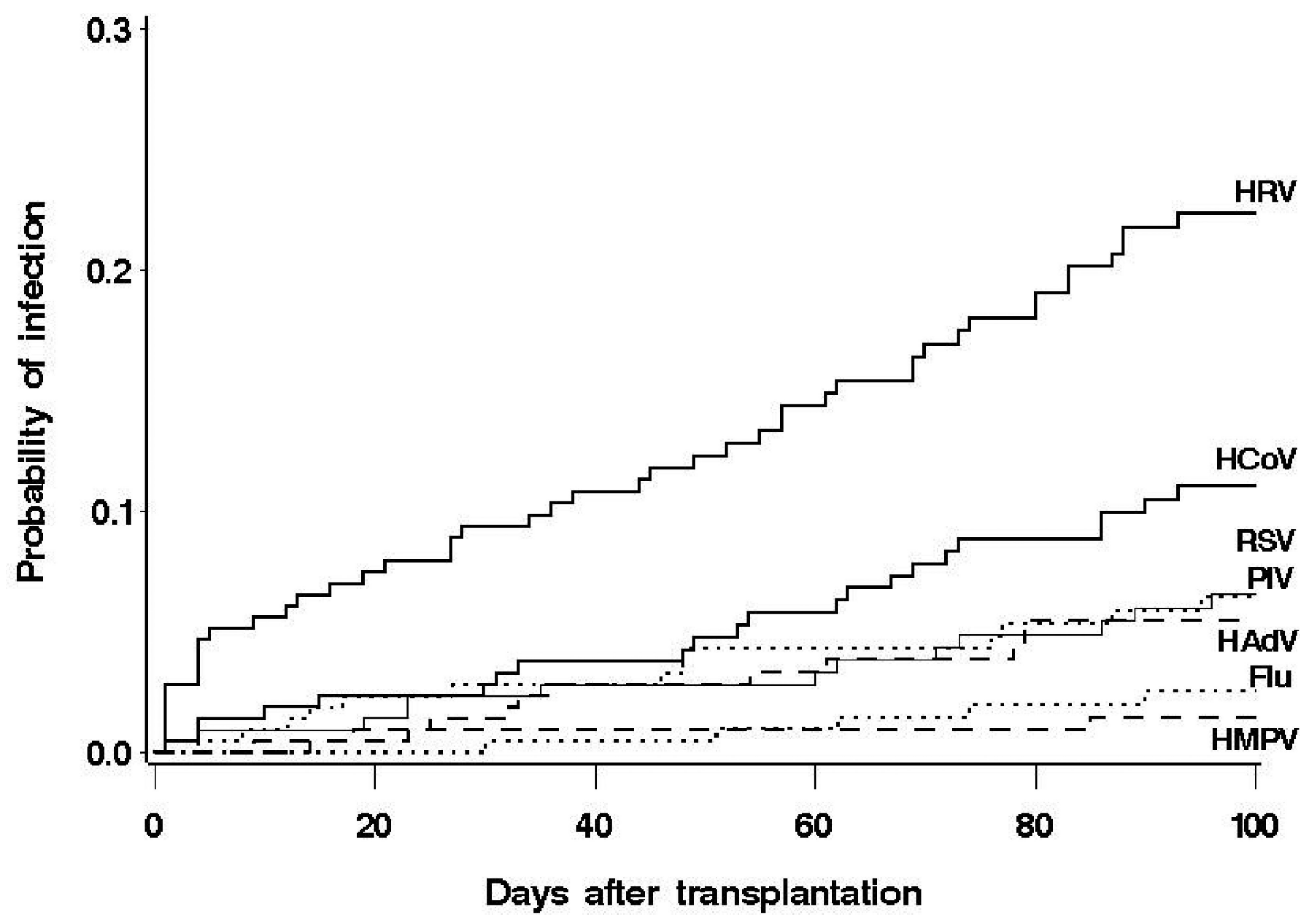

Figure 1. Cumulative incidence of first respiratory virus infection episodes in $\mathbf{2 1 5}$ allogeneic HCT recipients

At 100 days post-transplantation, the cumulative incidence estimates and $95 \%$ confidence intervals were $22.3 \%$ (16.5-28.1\%) for HRVs;11.1\% (6.7- 15.4\%) for HCoVs; $6.5 \%(3.1-$ $10.0 \%)$ for RSV and PIV (1, 2, 3 or 4$) ; 5.5 \%$ (2.3-8.6\%) for HAdV, $2.6 \%(0.3-4.8 \%)$ for influenza A or B; and 1.5\% (0-3.1\%) for HMPV.

HRV - Human rhinoviruses, HCoV- Human coronaviruses, RSV - Respiratory syncytial virus, PIV - Parainfluenza virus, HAdV - Human adenoviruses, Flu - Influenza, HMPV Human metapneumovirus 


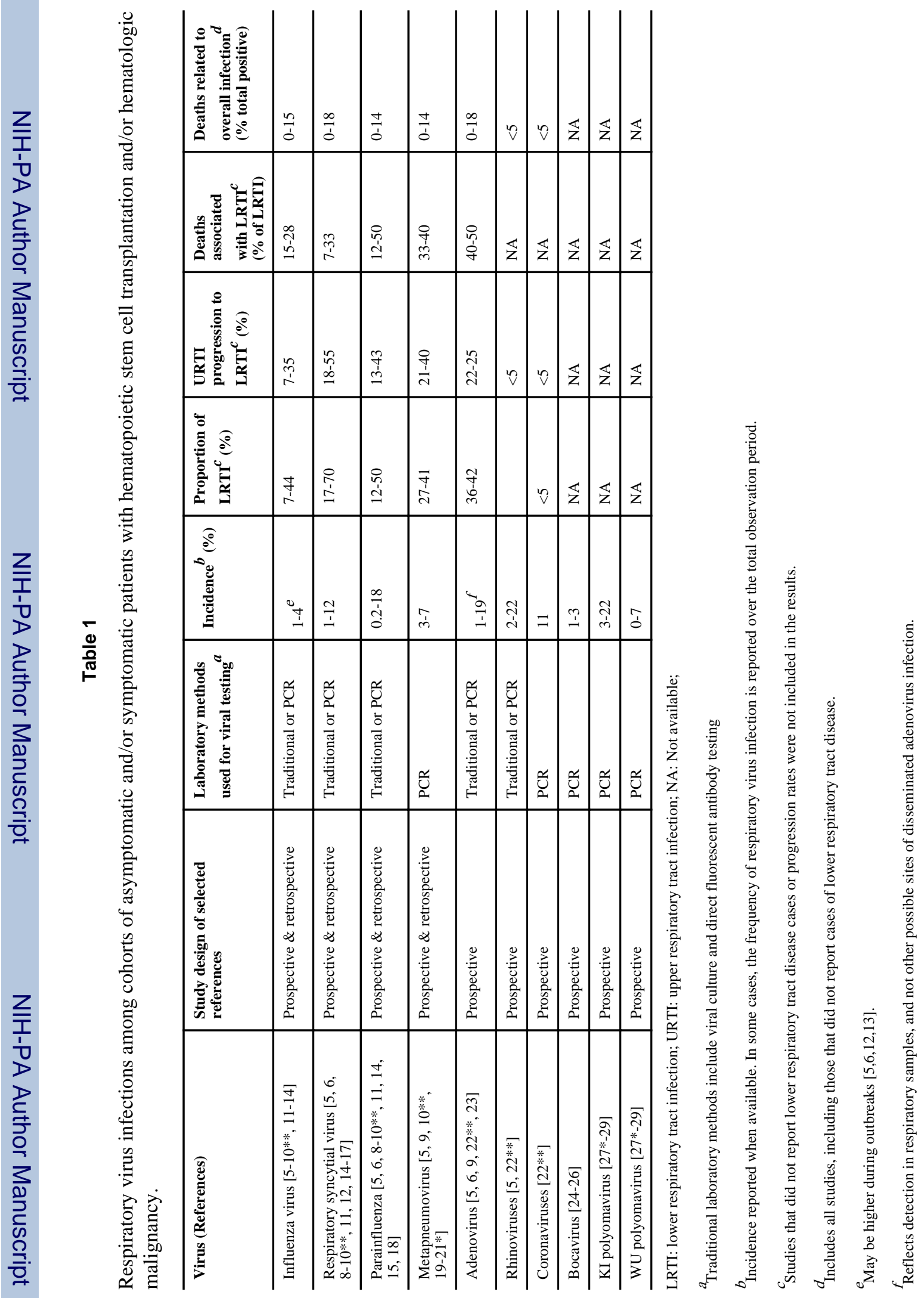




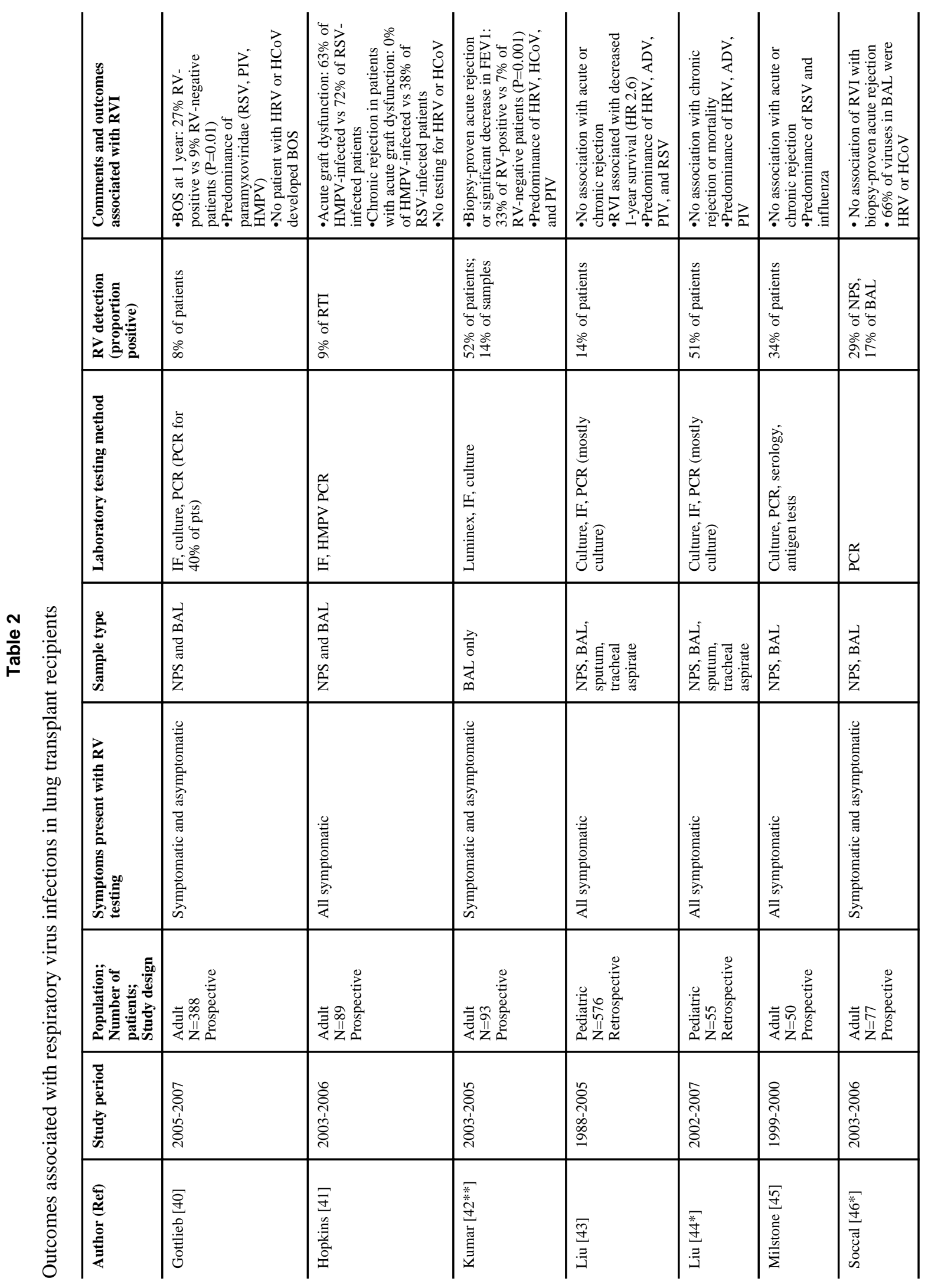




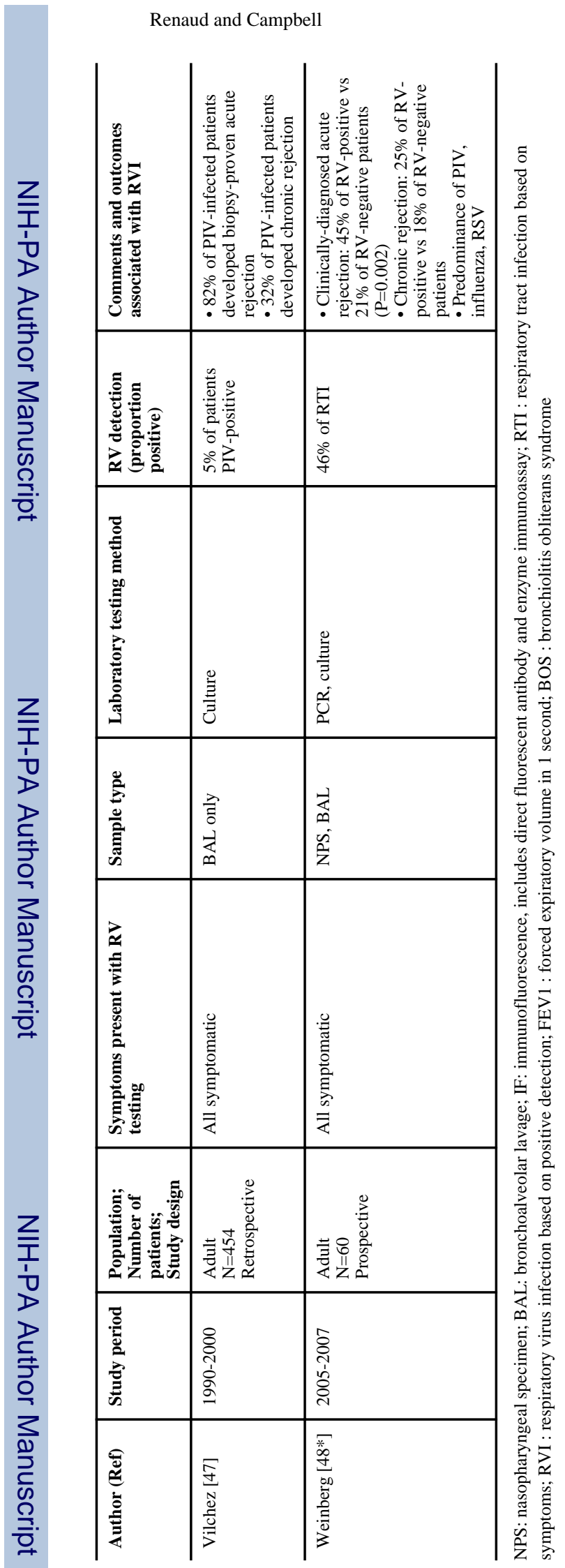

Page 20 


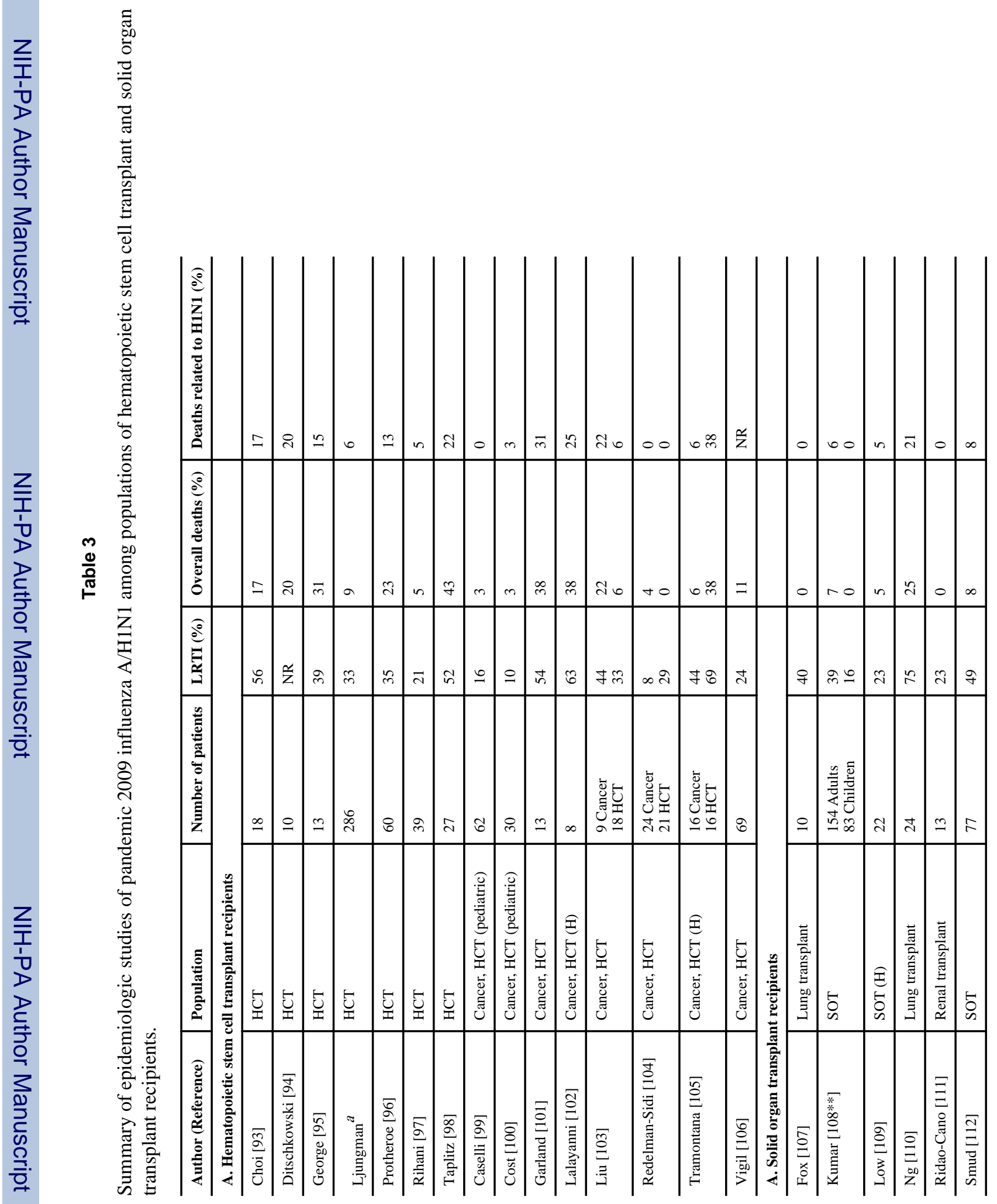




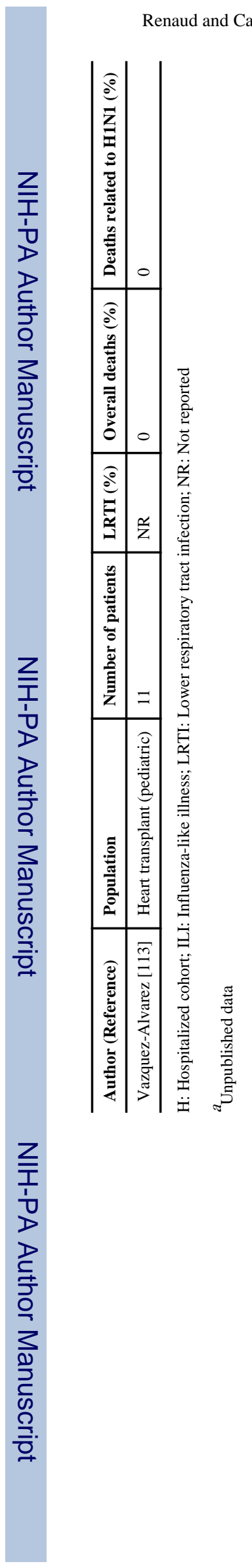

Page 22

Curr Opin Infect Dis. Author manuscript; available in PMC 2011 November 07. 